\title{
KEADILAN TERHADAP DOKTER PADA KASUS PENGGUNAAN OBAT YANG BELUM TERDAFTAR DI BPOM REPUBLIK INDONESIA
}

\author{
M Hendra Cordova Masputra ${ }^{2}$, J oko Setiyono², Irawati ${ }^{3}$ \\ IFakultas Hukum, Universitas Bandar Lampung \\ 2,3Fakultas Hukum, Universitas Diponegoro \\ droidcordova19@gmail.com
}

\begin{abstract}
The use of drugs or creams given by beauty clinic doctors can not be separated from supervision originating from the Food and Drug Supervisory Agency (BPOM). Not infrequently the doctor did not know that the drugs given have not been recorded on BPOM. This study aims to analyze justice in the provision of crimes against doctors related to the use of drugs that have not been registered with BPOM Research Methods using normative juridical methods with secondary legal materials. The results showed the verdict against the defendant was found guilty of using drugs that were not registered with BPOM, because ignorance of the drugs used was not registered with BPOM. The conclusion of this research is the case in Decision Number $2008 \mathrm{~K} / \mathrm{Pid}$. Sus / 2016, legally it is indeed guilty, however. J udges should be able to consider actions to provide relief from Dr. Triphena for its ignorance. As law enforcement officers become one of the very important institutions in enforcing existing laws. The operation of justice and legal certainty in court depends on each judge's decision.
\end{abstract}

Keywords: J ustice; Criminal; Professional Doctors; B POM.

\begin{abstract}
ABSTRAK
Penggunaan obat ataupun krim yang diberikan oleh dokter klinik kecantikan tidak lepas dari supervisi berasal Badan Pengawas Obat dan Makanan (BPOM). Tidak jarang Dokter ternyata tidak mengetahui bahwa obat yang diberikan belum tercatat pada BPOM. Penelitian ini bertujuan menganalisis Keadilan dalam pemberian pidana terhadap dokter terkait penggunaan obat yang belum terdaftar di BPOM. Metode Penelitian menggunakan metode yuridis normatif dengan bahan hukum sekunder. Hasil penelitian menunjukkan Putusan terhadap terdakwa dinyatakan bersalah karena menggunakan obat-obatan yang belum terdaftar di BPOM, karena ketidaktahuan terhadap obat digunakan belum terdaftar di BPOM. Kesimpulan penelitian ini adalah kasus dalam Putusan Nomor 2008 K/Pid.Sus/2016, secara legal memang bersalah, namun. Seharusnya hakim dapat mempertimbangkan tindakan untuk dapat memberikan keringanan terhadap Dr. Trifena terhadap ketidaktahuannya. Sebagai Aparat penegak hukum menjadi salah satu lembaga yang sangat penting dalam menegakkan hukum yang ada. Berjalannya suatu keadilan dan kepastian hukum di dalam pengadilan tergantung pada setiap keputusan dari hakim.
\end{abstract}

\section{Kata Kunci: Keadilan; Pidana; Profesi Dokter; BPOM.}

\footnotetext{
${ }^{*}$ Corresponding Author
} 
Jurnal Pembangunan Hukum Indonesia

Volume 2, Nomor 1, Tahun 2020
Program Studi Magister Ilmu Hukum Fakultas Hukum Universitas Diponegoro

\section{A. PENDAHULUAN}

Proses penegakan aturan harus menerapkan landasan-landasan yang paling krusial dalam kehidupan hukum yaitu suatu keadilan dan kepastian hukum. Suatu keadilan dan kepastian hukum tidak dapat dipisahkan dalam aturan dan menjadi faktor yang paling penting pada kelangsungan suatu aturan. Keadilan dan kepastian aturan sebagai tonggak sekaligus menjadi tolok ukur pada keberhasilan suatu hukum. Suatu pengadilan pada Indonesia Bila tidak menerapkan suatu keadilan dan kepastian hukum pada setiap proses aturan maka akan menyebabkan berbagai kendala juga persoalan yang akan merugikan banyak pihak (Sutiyoso, 2010). Karena bagaimanapun proses penegakkan hukum itu menjangkau sampai pada tahapan pembuatan hukum atau Undang-undang. Perumusan pikiran pembuat Undang-undang yang dituangkan dalam peraturan perundang-undangan akan turut menentukan bagaimana penegakan hukum itu nanti dijalankan (Jainah, 2012).

Hal tersebut juga berlaku dalam penegakan hukum di bidang kesehatan. Kesehatan adalah hal yang tidak dapat dipisahkan dari kehidupan manusia. Kesehatan memiliki strata yang sama dengan kebutuhan sandang, pangan dan papan dalam kebutuhan pokok manusia. Kesehatan itu sendiri adalah keadaan sejahtera dari badan, jiwa dan sosial yang memungkinkan setiap orang untuk hidup produktif baik secara sosial dan ekonomis. Untuk menjamin kualitas kesehatan maka, diperlukan Hukum Kesehatan yang mengatur keterjaminan kesehatan itu sendiri. Maka dibentuklah UndangUndang Republik Indonesia Nomor 36 tahun 2009 tentang Kesehatan (Agustina, 2015).

Undang-Undang Republik Indonesia Nomor 36 tahun 2009 tentang Kesehatan merupakan pembaharuan dari Undang-Undang Nomor 23 Tahun 1992. Undang-Undang baru ini yang bertujuan untuk memberikan payung hukum bagi peraturan perundang-undangan lainnya, kepastian hukum baik bagi masyarakat Indonesia penerima pelayanan kesehatan maupun tenaga kesehatan selaku pemberi pelayanan kesehatan (Koewarijanto, Chandrawila, Murni, 2015).

Praktek pelayanan kesehatan akan melibatkan tenaga kesehatan yaitu setiap orang yang mengabdikan diri dalam bidang kesehatan serta memiliki pengetahuan dan/atau keterampilan melalui pendidikan di bidang kesehatan yang untuk jenis tertentu memerlukan kewenangan untuk melakukan upaya kesehatan. Tenaga Kesehatan yang termasuk dalam kelompok tenaga medis terdiri atas dokter, dokter gigi, dokter spesialis, dan dokter gigi spesialis. Dokter sebagai tenaga medis disamping memiliki pengetahuan dan ketrampilan klinis juga harus harus memiliki komitmen dan perilaku yang sesuai dengan etika kedokteran dalam upaya menyembuhkan pasien.

Dokter memiliki tanggungjawab yang besar serta mulia, yang senantiasa wajib mengedepankan profesionalitas dalam memberikan pelayanan. Dokter tidak boleh ditentukan oleh sesuatu yang mengakibatkan hilangnya kebebasan dan 
Jurnal Pembangunan Hukum Indonesia

Volume 2, Nomor 1, Tahun 2020
Program Studi Magister IImu Hukum Fakultas Hukum Universitas Diponegoro kemandirian profesi. Seorang dokter yang tidak berhati-hati dalam menjalankan profesinya akan membuatnya jatuh ke dalam kegiatan yang melanggar etika. Hal ini disebabkan karena praktek pelayanan kesehatan bisa sebagai suatu komoditas perdagangan dengan obyek sentralnya ialah dokter. Dokter adalah alat promosi bagi perusahaan farmasi dan akibatnya tidak jarang mereka menjanjikan berbagai keuntungan pada dokter.

Dalam menjalankan profesinya, seringkali dokter melakukan praktek dispensing obat, yaitu membagikan obat pada pasien. namun pada praktiknya dokter tidak hanya membagikan obat, namun juga menyimpan sejumlah obat pada kawasan praktik pribadinya, termasuk juga oleh dokter klinik kecantikan. Penggunaan obat ataupun krim yang diberikan oleh dokter klinik kecantikan tidak lepas dari supervisi berasal Badan Pengawas Obat serta kuliner (BPOM) yang berdasarkan Peraturan kepala BPOM Nomor 14 Tahun 2014 memiliki tugas melaksanakan kebijakan di bidang pengawasan obat dan kuliner, yg meliputi pengawasan atas produk terapetik, narkotika, psikotropika, zat adiktif, obat tradisional, kosmetik, produk komplemen dan pengawasan atas keamanan pangan serta bahan berbahaya. aliran krim yg dijual sang klinik kecantikan harus memiliki izin edar asal BPOM.

Pengaturan tersebut berimplikasi bahwa setiap Dokter harus mengetahui Obat yang diberikan harus terdapat di BPOM. Aturan ini terlihat jelas pemberlakuan asas Fiksi hukum (presumtio iures de iure), yang menyatakan bahwa "setiap orang dianggap tahu akan undang-undang" sejak undangundang tersebut diberlakukan. Hal ini didasarkan satu alasan, bahwa manusia mempunyai kepentingan sejak lahir sampai meninggal. Setiap kepentingan manusia tadi selalu diancam oleh bahaya pada sekelilingnya. manusia memerlukan perlindungan kepentingan, yang dipenuhi oleh banyak sekali kaidah social, seperti kaidah aturan. Karena kaidah aturan melindungi kepentingan insan, maka wajib dipatuhi insan lainnya. sehingga ada pencerahan untuk mematuhi peraturan hukum, supaya kepentingannya sendiri terlindungi (HSB, 2016).

Terdapat kasus dimana dokter tidak mengetahui bahwa obat-obat yang dibagikan / disimpan belumlah memiliki izin edar dari BPOM. Seperti dalam Putusan Nomor 2008 K/Pid.Sus/2016, dengan terdakwa dr. Trifena binti Yusuf diputus bersalah karena menggunakan obat-obatan yang belum terdaftar di BPOM. Kasus tersebut ini diketahui bahwa Dr. Trifena diputus bersalah bukan karena meracik obat, seperti yang biasa dilakukan dokter spesialis kulit, namun menggunakan obatobatan yang belum terdaftar di BPOM. Ketidaktahuan dr. Trifena akan hukum yang akan menjeratnya tidak dapat membebaskannya / memaafkannya dari tuntutan hukum (ignorantia jurist non excusat), dalam putusan ini terlihat sangat jelas pemberlakuan asas Fiksi hukum (presumtio iures de iure).

Berdasarkan uraian diatas terlihat terdapat kesenjangan antara Proses penegakan aturan yang 
Jurnal Pembangunan Hukum Indonesia

Volume 2, Nomor 1, Tahun 2020
Program Studi Magister Ilmu Hukum Fakultas Hukum Universitas Diponegoro seharusnya keadilan dengan Putusan Nomor 2008 K/Pid.Sus/2016, yang memutus bersalah terdakwa bersalah karena menggunakan obat-obatan yang belum terdaftar di BPOM yang tidak diketahuinya. Sehingga dirasa menarik untuk meneliti tentang Keadilan dalam Putusan Nomor 2008 K/Pid. Sus/2016 yang memberikan Pidana Terhadap Dokter yang menggunakan Obat Yang Belum Terdaftar Di Badan Pengawas Obat Dan Makanan Republik Indonesia yang tidak diketahuinya.. maka tujuan penelitian ini adalah untuk meneliti mengenai Keadilan Dalam Pidana Terhadap Dokter Terkait Penggunaan Obat Yang Belum Terdaftar Di BPOM Republik Indonesia (Studi Putusan Nomor 2008 K/Pid. Sus/2016).

Berdasarkan penelusuran yang dilakukan pada berbagai pustaka, penelitian dengan tema terkait, belum pernah dibahas. Walaupun demikian Terdapat beberapa kajian penelitian yang dengan tema mengenai Profesi Dokter terkait Pemberian Obat dan terkait Pemidanaan terhadap Dokter.

Penelitian Mirza N. R. Poli menyatakan bahwa Tanggungjawab dan sanksi yang di terapkan bagi tenaga kesehatan ataupun apoteker yang melakukan kesalahan atau kelalaian dalam memberikan obat sehingga mengakibatkan pasien atau dalam hal ini konsumen menderita kerugian materi, fisik bahkan sampai meninggal dunia maka sanksi yang dapat diberikan adalah sanksi administrasi berupa teguran sampai pembekuan izin tenaga kesehatan kemudian sanksi keperdataan berupa ganti rugi dalam hal perbuatan melawan hukum dan wanprestasi bahkan sanksi pidana berupa hukuman fisik yaitu pemenjaraan dalam waktu tertentu (Poli, 2018).

Penelitian Yenny Fitri Z menyatakan bahwa dokter yang menerima pemberian dari perusahaan farmasi dapat dikenakan pidana. Hal ini tujuannya untuk mencegah terjadinya kolusi antara dokter dengan perusahaan farmasi agar tidak merugikan pasien dalam menerima resep obat dan mendapatkan pelayanan kesehatan (Fitri Z, 2018) Bagi dokter swasta yang menerima pemberian dari perusahaan farmasi dapat dikualifikasikan sebagai Tindak Pidana Suap yang diatur dalam Pasal 3 Undang-Undang Nomor 11 Tahun 1980 (UU Anti Suap), sedangkan bagi dokter pegawai negeri dapat dikualifikasikan sebagai Tindak Pidana Gratifikasi yang diatur dalam Pasal 12B Undang-Undang Nomor 31 Tahun 1999 junto Undang-Undang Nomor 20 Tahun 2001 Tentang Pemberantasan Tindak Pidana Korupsi (Undang-Undang Anti Korupsi).

Penelitian Hasrul Buamona menyatakan bahwa untuk menentukan kriteria dokter dalam melakukan kesalahan medis, tidak hanya bersandar pada kesalahan dalam hukum pidana saja. Dikarenakan kriteria untuk menentukan kesalahan medis dokter, harus melewati terlebih dahulu serangkaian pembuktian dalam ruang lingkup disiplin ilmu kedokteran dan etika kedokteran, yang kesemuanya dilakukan dengan cara audit medis yang dilakukan oleh Komite Medik di Rumah Sakit, sebagaimana ketentuan Pasal 49 Undang-Undang Nomor 29 Tahun 2004 Tentang Praktik Kedokteran, serta Peraturan Menteri Kesehatan Nomor 755 
Jurnal Pembangunan Hukum Indonesia

Volume 2, Nomor 1, Tahun 2020
Program Studi Magister IImu Hukum Fakultas Hukum Universitas Diponegoro
Tahun 2011 Tentang Penyelenggaraan Komite Medis di Rumah Sakit. Selain itu Peraturan Konsil Kedokteran Indonesia Nomor 4 Tahun 2011 Tentang Disiplin Profesional Dokter dan Dokter, merupakan elemen terpenting dan mendasar untuk membuktikan dokter telah melakukan kesalahan medis (malpraktik kedokteran) (Buamona, 2014).

Penelitian Khandakar Kohinur Akter menyatakan bahwa di Bangladesh, Undang-undang kelalaian medis adalah untuk melindungi pasien dari pelanggaran hak mereka atas kesehatan dan untuk melestarikan hukum perawatan kesehatan (Akter, 2013). Selain itu memastikan untuk menghukum para profesional medis yang melakukan pelanggaran tugas profesional dengan sengaja. Dalam artikel ini, upaya telah dilakukan untuk mengatasi ketentuan hukum yang ada tentang kelalaian medis di Bangladesh. Ini juga mengidentifikasi kekurangan utama dari ketentuan tersebut. Namun, harus diakui bahwa undang-undang tidak tepat dan memadai untuk menanggapi masalah ini.

Penelitian Kristin E. Schleiter menyatakan bahwa sementara mencegah kekerasan melekat dalam tugas dokter kepada pasien dan masyarakat, demikian juga tugas untuk menjaga kepercayaan pasien. Para dokter dengan hati-hati berjalan di antara etika dan hukum, khususnya dalam menghadapi kewajiban hukum untuk melanggar kewajiban utama yaitu untuk menjaga kerahasiaan (Schleiter, 2009).

Berdasarkan pada hal-hal yang telah diuraikan diatas, maka terdapat pembedaan dengan pembahasan penelitian ini dengan obyek penelitian adalah Putusan Nomor 2008 K/PID. SUS/2016. Selain itu penelitian ini akan membahas Keadilan dalam pemberian pidana terhadap dokter terkait penggunaan obat yang belum terdaftar di badan pengawas obat dan makanan republik indonesia.

\section{B. METODE PENELITIAN}

Jenis penelitian yang digunakan dalam penelitian ini adalah penelitian hukum normatif (Yuridis Normatif) yakni penelitian yang difokuskan untuk mengkaji penerapan kaidah-kaidah atau norma-norma dalam hukum positif. Penelitian hukum normatif disebut juga penelitian hukum doktrinal, karena penelitian ini dilakukan atau ditujukan hanya pada peraturan-peraturan yang tertulis atau bahan hukum yang lain. Penelitian hukum ini juga disebut sebagai penelitian kepustakaan. Hal ini disebabkan karena penelitian lebih banyak dilakukan terhadap data yang bersifat sekunder yang ada di perpustakaan dan menggunakan pendekatan perundang-undangan (statute approach) (Ibrahim, 2012). Dalam penelitian pada umumnya dibedakan antara data yang diperoleh secara langsung dari bahan-bahan pustaka. Yang diperoleh dari bahanbahan pustaka lazimnya dinamakan data sekunder (Soekanto, \& Mamudji, 2004).

\section{HASIL DAN PEMBAHASAN}

1. Kasus Posisi Pada Putusan Nomor 2008 K/PID. SUS/2016 Mengenai Pemberian Pidana 
Terhadap Dokter Terkait Penggunaan Obat Yang Belum Terdaftar Di BPOM

\section{a. Kronologi Kasus}

Pada hari Jum'at tanggal 19 April 2013 Tim Balai Besar POM didampingi Petugas Kepolisian Polda Jabar melakukan pemeriksaan beberapa klinik kecantikan dan salah satunya di klinik Kecantikan Estetika Rafa Health Beauty Life Style Jalan Raya Kopo Bihbul Nomor 45 Kopo Square, Kabupaten Bandung dengan pemilik/penanggungjawab klinik yaitu Terdakwa dr. TRIFENA binti YUSUF dengan pemeriksaan ke setiap ruangan dan ditemukan barang-barang dalam dus-dus dan rak-rak dalam sebuah gudang yang terpisah dari klinik bagian belakang yang merupakan produk sediaan berupa Proggesteron L-Cram, Progesterone B- Cream, Testosteron $2 \%$, Bio Sliming, Inno TDS Firming, Oxy Derma, Kojic Acid, Afa 10 Serum dan lain-lain, selanjutnya Tim Balai Besar POM menghitung, mengumpulkan dan menyita barang bukti tersebut yang selanjutnya barang bukti dibawa ke Balai POM untuk pemeriksaan lebih lanjut dan berdasarkan keterangan ahli Dra. Dela Triatmani, Apt. mengatakan bahwa seluruh barang bukti yang disita di kilinik Kecantikan Estetika Rafa Health Beauty Life Style tidak memiliki ijin edar karena berdasarkan data di Badan POM persediaan farmasi tersebut belum pernah didaftarkan dan kosmetik yang didaftarkan juga harus memenuhi ketentuan tentang label, pada label kosmetik harus jelas tercantum antara lain nama produk, nama dan alamat produsen atau importer/penyalur, ukuran/isi/berat bersih, komposisi, nomor izin edar, kode produksi, bulan dan tahun kadaluarsa bagi produk yang stabilitasnya kurang dari 30 (tiga puluh) bulan dan berdasarkan melihat kemasan kosmetika tersebut, produk kosmetik tersebut juga tidak memenuhi penandaan label kosmetika.

Barang-barang/bahan kosmetika tersebut dilakukan pengemasan ulang/repack dengan pencampuran/peracikan oleh saksi Angelka Yumi Cahya dan saksi Fitri Pratiwi atas petunjuk atau arahan dr. TRIFENA binti YUSUF dengan proses antara lain pembuatan Cream malam : KL-111 mengandung Melanox Forte + Vitacid 0,025, ACTC mengandung Vitacid 0,025 + Mediklin gel, VA-23 mengandung Vitacid 0,05, VA-1 mengandung Vitacid 0,025BHA, Cream Siang : SPF Moist mengandung SPF putih + MO cream selanjutnya proses BHA direpack dari Skinese AHA dan BHA Skin Refining cream, CHA-1 merupakan repack dari CHA-1 (Kaizen Aesthetic Medicore), ACN merupakan repack dari ACN (Kaizen Aesthetic Medicore), Serum B3H direpack dari Serum B3H (Immortal), SPF Warna direpack dari Primaderma Sun $P$ cream (First Medipharma), SPF Pink direpack dari Skineese Sun P cream or 30 Pink (First Medipharma), LHWC direpack dari Skinese Whitening Face cream (First Medipharma), WR Cool direpack dari Skinese Vitalizing Complex cream (First Medipharma), Toner Pink (Acne) direpack dari Face Tonic Acne (Immortal), SPF Putih direpack dari Skineese Sun P cream of 30 (First Medipharma), SPF Natural direpack dari Skineese Sun P cream of 30 Natural 
Jurnal Pembangunan Hukum Indonesia

Volume 2, Nomor 1, Tahun 2020
Program Studi Magister Ilmu Hukum Fakultas Hukum Universitas Diponegoro
(First Medipharma) dengan cara dikeluarkan dari kemasan dan dituangkan ke pot atau botol kemasan dan juga mengedarkan tidak memiliki izin edar ke pasien atau ke beberapa klinik kecantikan di antaranya klinik Rafa Tasikmalaya Jalan H.Z Mustofa Nomor 343 Tasikmalaya dan Apotek Rafa Jalan Raya Kopo Bihbul Nomor 45 Kabupaten Bandung, selain tempat tersebut Terdakwa dr. TRIFENA binti YUSUF melakukan pengiriman barang/obat-obatan dalam 1 (satu) bulan sekitar 30 kali dengan wilayah Jakarta, Medan, Pekanbaru, Palembang, Surabaya, Cianjur, Lombok, Bali, Semarang dan Bandung.

\section{b. Dakwaan}

dr. TRIFENA binti YUSUF telah didakwa oleh Penuntut Umum dengan dakwaan alternatif. Dengan dakwaan Kesatu dr. TRIFENA binti YUSUF dalam mengedarkan sediaan farmasi tidak memiliki ijin dari Kepala badan POM RI. Perbuatan Terdakwa diancam pidana sebagaimana diatur menurut Pasal 197 Undang-Undang Nomor 36 Tahun 2009 tentang Kesehatan, atau dakwaan kedua dr. TRIFENA binti YUSUF dalam mengedarkan sediaan farmasi tidak memiliki ijin dari Kepala BPOM RI. Perbuatan Terdakwa diancam pidana sebagaimana diatur menurut Pasal 196 Undang-Undang Nomor 36 Tahun 2009 tentang Kesehatan

\section{Putusan}

Putusan Pengadilan Negeri Bandung Nomor 1382/PID.B/2014/PN.BDG tanggal 04 Maret 2015 yang amar lengkapnya sebagai berikut :

1) Menyatakan Terdakwa dr. TRIFENA binti YUSUF terbukti secara sah dan meyakinkan bersalah melakukan tindak pidana "Mengedarkan Sediaan Farmasi tanpa Izin Edar" melanggar Pasal 197 Undang-Undang Nomor 36 Tahun 2009 tentang Kesehatan, dalam dakwaan pertama ;

2) Menjatuhkan pidana penjara oleh karena itu terhadap Terdakwa tersebut selama 6 (enam) bulan, dan pidana denda sebesar Rp500.000.000,00 (lima ratus juta rupiah) dan Subsidair selama 2 (dua) bulan kurungan ;

3) Menetapkan pidana tersebut tidak usah dijalani kecuali jika dikemudian hari ada putusan Hakim yang menentukan lain disebabkan karena Terpidana melakukan suatu tindak pidana sebelum masa percobaan 1 (satu) tahun berakhir

4) Menetapkan Terdakwa tetap berada dalam tahanan kota ;

5) Menetapkan barang bukti berupa :

a) Foto copi surat tetap terlampir di dalam berkas perkara ;

b) Sediaan Farmasi tanpa izin edar yaitu :

Barang bukti yang ditemukan di TKP telah disita oleh PPNS Balai Besar POM Bandung sesuai dengan Surat Tanda Penerimaan Barang Bukti Nomor STPB/18/IV/2013/BBPOM-PPNS tanggal 19 April 2013 dan Nomor STPB/19/IV/2013/BBPOM-PPNS tanggal 19 April 2013 sesuai dengan Berita Acara Penyitaan tanggal 19 April 2013 (foto copy terlampir) ;

Dirampas untuk dimusnahkan ;

6) Membebankan biaya perkara sebesar Rp5.000,00 (lima ribu rupiah) ; 
Jurnal Pembangunan Hukum Indonesia

Volume 2, Nomor 1, Tahun 2020
Program Studi Magister Ilmu Hukum Fakultas Hukum Universitas Diponegoro
Kemudian terdakwa mengajukan banding ke Pengadilan Tinggi Bandung. Dalam Banding melalui putusan Pengadilan Tinggi Bandung Nomor 116/Pid/2015/PT.Bdg. tanggal 29 Juni 2015 yang amar lengkapnya sebagai berikut :

- Menerima permintaan banding dari Pembanding ;

- Memperbaiki putusan Pengadilan Negeri Bandung Nomor 1382 / Pid.B / 2014 / PN.Bdg tanggal 04 Maret 2015 sekedar mengenai besarnya denda yang dijatuhkan kepada Terdakwa sehingga amar selengkapnya sebagai berikut ;

1) Menyatakan Terdakwa dr. TRIFENA binti YUSUF terbukti secara sah dan meyakinkan bersalah melakukan tindak pidana "Mengedarkan Sediaan Farmasi tanpa Izin Edar" melanggar Pasal 197 Undang-Undang Nomor 36 Tahun 2009 tentang Kesehatan, dalam dakwaan pertama ;

2) Menjatuhkan pidana penjara oleh karena itu terhadap Terdakwa tersebut selama 6 (enam) bulan dan pidana denda sebesar Rp.50.000.000,00 (lima puluh juta rupiah) dan subsidair selama 1 (satu) bulan kurungan ;

3) Menetapkan pidana tersebut tidak usah dijalani kecuali jika dikemudian hari ada putusan Hakim yang menentukan lain disebabkan karena Terpidana melakukan suatu tindak pidana sebelum masa percobaan 1 (satu) tahun berakhir ;

4) Menetapkan barang bukti berupa : a. Foto copi surat tetap terlampir di dalam berkas perkara ;

b. Sediaan Farmasi tanpa izin edar yaitu : Barang bukti yang ditemukan di TKP telah disita oleh PPNS Balai Besar POM Bandung sesuai dengan Surat Tanda Penerimaan Barang Bukti Nomor STPB/18/IV/2013/BBPOM - PPNS tanggal 19 April 2013 dan Nomor STPB/19/IV/2013/BBPOM - PPNS tanggal 19 April 2013 sesuai dengan Berita Acara Penyitaan tanggal 19 April 2013 (foto copy terlampir) ;

Dirampas untuk dimusnahkan ;

5) Membebankan biaya perkara pada tingkat banding kepada Terdakwa sebesar Rp5.000,00 (lima ribu rupiah) ;

Kemudian diajukan kasasi ke Mahkamah Agung. Oleh Mahkamah Agung dalam Putusan Kasasi Nomor 2008 K/PID. SUS/2016, yaitu

Menolak permohonan kasasi dari Pemohon Kasasi II/Terdakwa dr. TRIFENA binti YUSUF, tersebut ;

Mengabulkan permohonan kasasi dari Pemohon Kasasi I/Penuntut Umum pada Kejaksaan Negeri Bandung tersebut ;

Membatalkan putusan Pengadilan Tinggi Bandung Nomor 116/Pid/2015/ PT.Bdg. tanggal 29 Juni 2015, yang memperbaiki amar putusan Pengadilan Negeri Bandung Nomor 1382/PID.B/2014/PN.BDG tanggal 04 Maret 2015

1) Menyatakan Terdakwa dr. TRIFENA binti YUSUF telah terbukti secara sah dan meyakinkan 
bersalah melakukan tindak pidana "Dengan Sengaja Memproduksi atau Mengedarkan Sediaan Farmasi dan/atau Alat Kesehatan Yang Tidak Memenuhi Standard dan atau Persyaratan Keamanan, Khasiat atau Kemanfaatan dan Mutu"

2) Menjatuhkan pidana terhadap Terdakwa oleh karena itu dengan pidana penjara selama 1 (satu) tahun dan pidana denda sebesar R.p800.000.000,00 (delapan ratus juta rupiah) dengan ketentuan jika denda tersebut tidak dibayar maka diganti dengan kurungan selama 3 (tiga) bulan ;

3) Menetapkan lamanya Terdakwa berada dalam tahanan dikurangkan seluruhnya dari pidana yang dijatuhkan ;

4) Menetapkan barang bukti berupa :

a) Foto copy surat tetap terlampir di dalam berkas perkara ;

b) Sediaan Farmasi tanpa izin edar yaitu : Barang bukti yang ditemukan di TKP telah disita oleh PPNS Balai Besar POM Bandung sesuai dengan Surat Tanda Penerimaan Barang Bukti Nomor STPB/18/IV/2013/BBPOM-PPNS tanggal 19 April 2013 dan Nomor STPB/19/IV/2013/BBPOMPPNS tanggal 19 April 2013 sesuai dengan Berita Acara Penyitaan tanggal 19 April 2013 (foto copy terlampir);

Dirampas untuk dimusnahkan ;

Membebankan Terdakwa tersebut untuk membayar biaya perkara pada tingkat kasasi sebesar Rp2.500,00 (dua ribu lima ratus rupiah) ;
2. Keadilan Dalam Pemberian Pidana Terhadap Dokter Terhadap Penggunaan Obat Yang Belum Terdaftar Di Badan Pengawas Obat Dan Makanan Republik Indonesia (Studi Putusan Nomor 2008 K/Pid. Sus/2016)

Dalam suatu Pranata hukum terdapat berbagai pihak yang akan menegakkan hukum yang berlaku di Indonesia. Pihak-pihak tersebut menjalankan suatu penegakan hukum sebagai akibat adanya suatu pelanggaran hukum. Menertibkan masyarakat maupun mengatur masyarakat agar sesuai dengan norma dan aturan yang berlaku di sebuah negara tidaklah mudah dalam penerapannya di dalam kehidupan bermasyarakat. Terdapat lembaga khusus yang penegakan hukum maupun yang ahli dalam bidang hukum yaitu aparat penegak hukum. Penegak hukum berfungsi dalam menegakkan, menganalisis, dan menyelesaikan suatu perkara yang tidak sesuai dengan hukum yang berlaku di Indonesia. Salah satu dari aparat penegak hukum di Indonesia adalah lembaga pengadilan, yang berfungsi untuk menegakkan hukum yang berlaku (Putri, \& Arifin, 2018).

Penegakan hukum pidana pada hakikatnya merupakan penerapan terhadap peraturan perundang-undangan dan kebijakan aparat dalam menerapkan peraturan. Penegakan hukum juga dapat diartikan sebagai penyelenggaraan hukum oleh petugas penegak hukum dan oleh setiap orang yang berkepentingan sesuai dengan masing-masing menurut hukum serta peraturan perundangundangan yang berlaku. Dengan demikian 
Jurnal Pembangunan Hukum Indonesia

Volume 2, Nomor 1, Tahun 2020
Program Studi Magister Ilmu Hukum Fakultas Hukum Universitas Diponegoro penegakan hukum merupakan suatu sistem yang menyangkut penyerasian antara nilai dengan kaidah serta perilaku nyata manusia (Arief, 2005).

Pada kasus dr. Trifena binti Yusuf, secara dilihat dari aspek hukum, memang melakukan pelanggaran Pasal 196 Undang-Undang Nomor 36 Tahun 2009 tentang Kesehatan, yaitu "Setiap orang yang dengan sengaja memproduksi atau mengedarkan sediaan farmasi dan/atau alat kesehatan yang tidak memenuhi standar dan/atau persyaratan keamanan, khasiat atau kemanfaatan, dan mutu sebagaimana dimaksud dalam Pasal 98 ayat (2) dan ayat (3) dipidana dengan pidana penjara paling lama 10 (sepuluh) tahun dan denda paling banyak Rp1.000.000.000,00 (satu miliar rupiah)".

Selain itu juga melanggar Undang-undang Perlindungan Konsumen melalui Pasal 108 Ayat (1) menentukan, bahwa praktik kefarmasian dalam pengadaan, distribusi \& pelayanan sediaan farmasi harus dilakukan oleh tenaga kesehatan tertentu yang mempunyai keakhlian dan kewenangan untuk itu dan Ayat (2) menentukan pengaturan lebih lanjut akan diatur dengan Peraturan Pemerintah (PP) jo. ketentuan Pidana dalam UUK melalui Pasal 198, ditetapkan tentang barangsiapa yang tanpa kewenangan \& keakhlian melakukan pekerjaan seperti Pasal 108 Ayat (1), maka akan dikenakan sanksi pidana denda Rp. 100.000.000,-. Telah diketahui bahwa dr. TRIFENA telah terbukti menggunakan obat - obatan pada klinik miliknya yang belum memiliki ijin edar dari BPOM. Sehingga diketahui bahwa melakukan pelanggaran Pasal 196
Undang-Undang Nomor 36 Tahun 2009 tentang Kesehatan. Namun dalam Pasal tersebut terdapat kata - kata dengan sengaja, sedangkan menurut pengakuan dari dr Trifena bahwa ia tidak mengetahui bahwa obat - obatan yang digunakan pada kliniknya belum memenuhi ijin edar dari BPOM. Namun hal ini tidak dapat dijadikan alasan bagi terdakwa dalam hal ini dr, Trifena yang menyatakan atas ketidaktauannya bahwa produk dan obat - obatan yang digunakan pada kliniknya belum memiliki ijin edar. Artinya bahwa adanya unsur kelalaian dari dr Trifena, yang tidak memastikan dengan benar mengenai produk dan obat - obatan yang digunakan pada kliniknya.

Untuk dapat melaksanakan Undang-Undang Nomor 36 Tahun 2009 tentang Kesehatan dan Undang-undang Perlindungan Konsumen membutuhkan Peraturan Pelaksanaan, karena disyaratkan adanya Peraturan Pemerintah yang mengatur lebih lanjut. PP tentang pengadaan, penyimpanan dan pendistribusian obat telah dibentuk yakni Peraturan Pemerintah Republik Indonesia Nomor 72 Tahun 1998 tentang Pengamanan Sediaan Farmasi dan Alat kesehatan yaitu pasal 9 (1) sediaan farmasi dan alat kesehatan hanya dapat diedarkan setelah memperoleh ijin edar dari Menteri (2) dikecualikan dari ketentuan sebagaimana dimaksud dalam ayat (1) bagi sediaan farmasi yang berupa obat tradisional yang diproduksi oleh perorangan

Akan tetapi putusan hakim tersebut mengundang keberatan. Terdapat anggapan bahwa seharusnya hakim mempertimbangkan tindakan Dr. 
Jurnal Pembangunan Hukum Indonesia

Volume 2, Nomor 1, Tahun 2020
Program Studi Magister IImu Hukum Fakultas Hukum Universitas Diponegoro
Trifena tidak merugikan siapapun dan bilapun tidak membebaskan, dapat memberikan keringanan terhadap Dr. Trifena terhadap ketidaktahuannya. Namun hal ini tidak begitu saja dapat dijadikan alasan bagi terdakwa dalam hal ini dr, Trifena yang menyatakan atas ketidaktauannya bahwa produk dan obat - obatan yang digunakan pada kliniknya belum memiliki ijin edar. Artinya bahwa hakim memandang adanya unsur kelalaian dari dr Trifena, yang tidak memastikan dengan benar mengenai produk dan obat - obatan yang digunakan pada kliniknya.

Paparan putusan hukum tersebut memperlihatkan permasalahan umum dalam penegakan hukum yaitu; persoalan kesetaraan di hadapan hukum, kemudian asas keadilan moral dan kekeluargaan dalam hukum yang diterapkan dalam penyelesaian kasus-kasus hukum. Karena kompleksitas kehidupan manusia memberikan banyak motif dalam melakukan sebuah tindak hukum dan hukum sendiri harus mampu menyelesaikannya. Sehingga hukum perlu memperhatikan banyak aspek khususnya pada tataran sosial dan kepastian hukum yang seharusnya diperhatikan dalam setiap keputusan hukum yang diambil oleh penegak hukum seperti hakim aparat penegak hukum lainnya. Bukan sekedar himbauan, bahwa hukum di Indonesia perlu mengadopsi hukum-hukum yang berasal dari kearifan lokal sendiri sebagai hukum yang diundangkan (ius constitutum) dengan segera bukan lagi sebagai hukum nasional yang dicita-citakan (ius constituendum). Sebab itulah pemerintah seharusnya segera membentuk peraturan baik pidana atau perdata yang mampu mengayomi masyarakat Indonesia agar tidak terjadi penegakan hukum yang tajam ke bawah namun tumpul ke atas (Hoesein, 2013).

Kasus Pemidanaan terhadap Dr. Trifena, di satu sisi secara normatif, perbuatan tersebut memang melanggar tindak pidana, namun sebaiknya Hukum mampu memberikan konsep keadilan yang mampu memperhatikan asas distributif, kesesuaian hukum dengan tindakan yang dilakukan.

Implikasi dari adanya keadilan ini akan terbawa dalam konsep hukuman, punishment, yang diberikan. Sudah sepantasnya manusia Indonesia memiliki karakter yang selalu berdimensi dua di mana untuk menjalankan hukum pun haruslah sesuai dengan kondisi yang ada demi kepentingan bersama dalam lingkup sosial (Husna, 2014). Dengan kondisi yang ada mampu melindungi kepentingan bersama namun juga tetap memperhatikan keadilan bagi individu.

Melihat kasus tersebut, dapat dikatakan bahwa hukum di Indonesia masih belum sesuai dengan citacita bangsa yang menginginkan hukum yang progresif dan membebaskan dari ketidakadilan. Sebagaimana cita-cia bangsa Indonesia yang ada pada pembukaan Undang Undang Dasar 1945 pada alinea keempat,

" kemudian daripada itu untuk membentuk suatu Pemerintah Negara Indonesia yang melindungi segenap bangsa Indonesia dan seluruh tumpah darah Indonesia dan untuk memajukan kesejahteraan umum, mencerdaskan kehidupan bangsa, dan ikut melaksanakan kertertiban dunia yang berdasarkan kemerdekaan, perdamaian abadi dan keadilan sosial...." 
Jurnal Pembangunan Hukum Indonesia

Volume 2, Nomor 1, Tahun 2020
Program Studi Magister Ilmu Hukum Fakultas Hukum Universitas Diponegoro agaknya belum dapt terwujud dengan baik.

Persoalan yang ada pada kasus tersebut, adalah Pemberian Sanksi hukum dipandang secara hanya secara positivistik dengan tidak memperhatikan konsep keadilan yang ada padanya. Padahal hukum bertujuan untuk mencapai kebahagiaan bersama. Hakim pada kasus tersebut mendasarkan diri pada hukum secara lettered artinya, hukum hanya dibaca secara tekstual dan tidak melihat secara kontekstual pada kejadian tersebut. Efeknya adalah masyarakat menganggap hakim belum melihat sisi keadilan dengan baik sebagaimana yang diharapkan masyarakat. Banyak yang membanding-bandingkan keputusan dalam terhadap berat hukuman yang dijatuhkan dengan berat hukuman yang diterima terdakwa pada kasus lain seperti korupsi. Masyarkat mempunyai hak untuk menilai apakah putusan yang diberikan tersebut sesuai tidak dengan yang dilakukan terdakwa atau tidak. Hal ini sesuai dengan apa yang dikatakan Rawls dimana masyarakat berhak menilai dan menimbang apapun yang ada pada hukum karena dianggap tidak sesuai dengan apa yang seharusnya.

Persoalan pemberian sanksi melalui putusan hukum yang dibebankan kepada setiap hakim menjadi sebuah dilema karena jika hakim tidak mampu bijak dalam memberikan putusan maka yang terjadi adalah keputusan yang kurang sesuai dengan yang seharusnya diterima oleh terdakwa.

Persoalan moralitas dan integritas hakim untuk selalu konsisten pada setiap keputusannya sebaiknya bisa dijadikan patokan yang baku dan wajib untuk selalu dijaga. jika setiap manusia tidak hanya hakim pemutus perkara hukum tetap berpegang teguh pada keyakinan akan kebenaran, tetapi semua elemen penegakan hukum ikut andil dalam menjaga kebenaran dan kebijaksanaan (Putra, 2014).

Oleh karena itu Bagir Manan (Wantu, 2012), menyatakan bahwa suatu hal yang bertentangan dengan tugas universal, kalau hakim dituntut mengesampingkan hukum atas nama keadilan. Hakim dimanapun harus memutus menurut hukum. Sehingga keadilan yang harus ditemukan oleh hakim adalah keadilan menurut hukum. Dalam perspektif positivistik, keadilan memang selalu dianggap relatif, karena adil bagi seseorang belum tentu adil bagi orang lain, adil untuk rnasa ini (kontemporer) belum tentu akan adil untuk masa yang akan datang. Jadi keadilan dapat saja selalu berbeda-beda menurut orang tempat dan waktu (Luthan, 2012). Ini seakan menjadi justifikasi atas pernyataan Hans Kelsen (Samekto, 2019) berikut; "J ustice is primarily a possible, but not a necessary, quality of a social order regulating the mutual relation of men".

Sanksi dalam Hukum seharusnya mampu memberikan konsep keadilan yang mampu memperhatikan asas distributif, kesesuaian hukum dengan tindakan yang dilakukan serta Implikasi dari adanya keadilan ini akan juga terbawa dalam konsep hukuman, punishment, yang diberikan (Hakim, 2017). Mengingat manusia adalah makhluk monopluralistik yang mencakup sifat dan kedudukan kodrat manusia sebagai jiwa dan raga, bersifat individual dan sosial dan sebagai pribadi dan makhluk Tuhan. Sudah 
Jurnal Pembangunan Hukum Indonesia

Volume 2, Nomor 1, Tahun 2020
Program Studi Magister IImu Hukum Fakultas Hukum Universitas Diponegoro sepantasnya manusia Indonesia memiliki karakter yang selalu berdimensi dua di mana untuk menjalankan hukum pun haruslah sesuai dengan kodrat dan sifat manusia demi kepentingan bersama dalam lingkup sosial.

\section{SIMPULAN}

Dalam Putusan Nomor 2008 K/Pid.Sus/2016, dengan terdakwa dr. Trifena binti Yusuf diputus bersalah karena menggunakan obat-obatan yang belum terdaftar di BPOM. Dr. Trifena diputus bersalah bukan karena meracik obat, seperti yang biasa dilakukan dokter spesialis kulit, namun menggunakan obat-obatan yang belum terdaftar di BPOM. Ketidaktahuan dr. Trifena akan hukum yang akan menjeratnya tidak dapat membebaskannya I memaafkannya dari tuntutan hukum (ignorantia jurist non excusat), dalam putusan ini terlihat sangat jelas pemberlakuan asas Fiksi hukum (presumtio iures de iure), yang menyatakan bahwa "setiap orang dianggap tahu akan undang-undang" sejak undangundang tersebut diberlakukan.

Pada kasus dalam Putusan Nomor 2008 K/Pid. Sus/2016, dengan terdakwa, secara hukum pidana memang bersalah. Akan tetapi putusan hakim tersebut mengundang keberatan. Seharusnya hakim dapat mempertimbangkan bahwa tindakan Dr. Trifena terdapat unsur kelalaian namun sebaiknya hakim dapat memberikan keringanan terhadap Dr. Trifena terhadap ketidaktahuannya. Aparat penegak hukum menjadi salah satu lembaga yang sangat penting dalam menegakkan hukum yang ada. Aparat penegak hukum yang paling penting dalam penegakan hukum salah satunya adalah hakim. Berjalannya suatu keadilan dan kepastian hukum di dalam pengadilan tergantung pada setian keputusan dari seoarang hakim.

\section{DAFTAR PUSTAKA}

\section{BUKU}

Arief, Barda N. (2005) Beberapa Aspek Kebijakan Penegakkan dan Pengembangan Hukum Pidana. Bandung: Citra Aditya Bakti.

Soekanto, Soejono., \& Mamudji, Sri. (2004) Penelitian Hukum Normatif. Jakarta: Raja Grafindo Persada.

\section{J URNAL}

Akter, Khandakar K. (2013). A Contextual Analysis of the Medical Negligence in Bangladesh: Laws and Practices. The Northern University J ournal of Law, Vol. IV, pp.77-81, p.71,79,80.

Agustina, B. (2015). Kewenangan Pemerintah Dalam Perlindungan Hukum Pelayanan Kesehatan Tradisional Ditinjau Dari Undang-Undang Republik Indonesia Nomor 36 Tahun 2009 Tentang Kesehatan. Jurnal Wawasan Hukum, Vol. 32, (No. 1, Februari 2015). pp. 82-98, p.83.

Hoesein, Zainal A. (2013). Mewujudkan Peradilan Dalam Perspektif Pembaruan Hukum. J urnal Media Hukum, Vol.20, (No.1), p.19.

Buamona, H. (2014). Tanggung Jawab Pidana Dokter Dalam Kesalahan Medis (Analisis 
Jurnal Pembangunan Hukum Indonesia

Volume 2, Nomor 1, Tahun 2020
Program Studi Magister Ilmu Hukum Fakultas Hukum Universitas Diponegoro
Hukum Putusan Kasasi Nomor 365 K/Pid/2012). Al-Mazahib, Vol.2, (No. 2, Desember), pp. 215-238, p. 215, 217, 237.

Hakim, A. (2017). Menakar Rasa Keadilan Pada Putusan Hakim Perdata Terhadap Pihak Ketiga Yang Bukan Pihak Berdasarkan Perspektif Negara Hukum Pancasila. J urnal Hukum dan Peradilan, Vol.6, (No.3, November), pp. 361 - 378, p. 365.

HSB, Ali Marwan. (2016). Mengkritisi Pemberlakuan

Teori Fiksi Hukum (Criticising Enactment of Law Fiction Theory). Jurnal Penelitian Hukum DE JURE, Vol. 16, (No. 3, September), pp. 251 - 264, p. 259.

Husna, U. (2014). Proses Penyelesaian Perkara Korupsi Kedalam Putusan Perdata (Studi Kasus Di Pengadilan Negeri Sragen). J urisprudence, Vol. 4, (No. 1, Maret), pp. 814, p. 12.

Koewarijanto, Harjono., Chandrawila, Wila., Murni, Tri Wahyu. (2015). Penelitian Terapi Sel Punca Darah Tali Pusat Dikaitkan Dengan Asas Kemanfaatan. SOEPRA ; Jurnal Hukum Kesehatan, Vol. 1 (No. 1), pp. 35-52, p. 36

Luthan, S. (2012). Dialektika Hukum dan Moral dalam Perspektif Filsafat Hukum. Jurnal Hukum lus Quita lustum, Vol 19, (No. 4), pp. 506-523, p. 512.

Wantu, Fence M. (2012). Mewujudkan Kepastian Hukum, Keadilan dan Kemanfaatan Dalam Putusan Hakim di Peradilan Perdata. J urnal
Dinamika Hukum, Vol.12, (No 3, September), pp. 56-73, p. 62.

Jainah, Zainab O. (2012). Penegakan Hukum Dalam Masyarakat. J ournal of Development, Vol.3, (No. 2, Agustus), pp. 162-172, p. 168

Putra, Surya Desismansyah E. (2014). Bingkai Keadilan Hukum Pancasila Dalam Perspektif Hukum Dan Relevansinya Dengan Keadilan di Indonesia. Jurnal Pendidikan Pancasila dan Kewarganegaraan, Vol. 27, (No. 1, Pebruari), pp. 49-57, p. 52

Putri, Kania Dewi Andhika., \& Arifin, Ridwan. (2018). Tinjauan Teoritis Keadilan Dan Kepastian Dalam Hukum di Indonesia. Mimbar Yustitia, Vol. 2 (No. 2, Desember), pp. 142-158, p. 152

Poli, Mirza N. R. (2018). Kesalahan Pemberian Obat Dalam Perspektif Undang-Undang Nomor 8 Tahun 1999 Tentang Perlindungan Konsumen. Lex Privatum, Vol. VI, (No. 4, Juni), pp. 109-116

Samekto, A. (2019). Menelusuri Akar Pemikiran Hans Kelsen Tentang Stufenbeautheorie Dalam Pendekatan Normatif-Filosofis. Jurnal Hukum Progresif, Vol. 7, (No. 1, Apr), pp. 119, p. 1,3,18.

Schleiter, Kristin E. (2009). When Patient-Physician Confidentiality Conflicts with the Law. Virtual Mentor, Vol. 11, (No. 2), pp. 46-148, p. 47, 50,146

Sutiyoso, B. (2010). Mencari Format Ideal Keadilan Putusan dalam Putusan. Jurnal Hukum; Ius 
Jurnal Pembangunan Hukum Indonesia

Volume 2, Nomor 1, Tahun 2020
Program Studi Magister Ilmu Hukum Fakultas Hukum Universitas Diponegoro

Quia lustrum, Vol.17, (Nomor 2, April), pp.

217-232, p. 220

Fitri Z, Y. (2018). Tinjauan Hukum Dokter Yang

Berkolusi Dengan Perusahaan Farmasi

Dalam Meresepkan Obat. J urnal Cendekia

Hukum, Vol. 3, (No 2, Maret), pp. 272-282, p.

273,280 